\title{
Exploring the effects of individual innovativeness dimensions on performance: a study with pharmaceutical managers*
}

\author{
Nilay Tarhan ${ }^{1,2}$ (D), Sevgi Șar ${ }^{1}$ (D) \\ ${ }^{1}$ Ankara University, Faculty of Pharmacy, Department of Pharmacy Management, Ankara, Turkey \\ ${ }^{2}$ Izmir Katip Celebi University, Faculty of Pharmacy, Department of Pharmacy Management, Izmir, Turkey
}

ORCID IDs of the authors: N.T. 0000-0002-3085-1178; S.Ș.0000-0002-2816-9575

Cite this article as: Tarhan, N., \& Sar, S. (2021). Exploring the effects of individual innovativeness dimensions on performance: a study with pharmaceutical managers. Istanbul Journal of Pharmacy, 51 (2), 256-262.

\begin{abstract}
Background and Aims: Innovation is a crucial factor for individuals and businesses, particularly in the period of Industry 4.0 . The objectives of the present study are to explore the factor structure of the Individual Innovativeness Scale (IS) in a manager sample, and then to investigate the dimensions' impact on performance.

Methods: A questionnaire was administered to managers in the pharmaceutical industry. Factor structure of the Individual Innovativeness Scale was determined via exploratory and confirmatory factor analyses. Afterwards, impacts of the dimensions on performance were assigned.

Results: After exploratory and confirmatory factor analyses, three dimensions emerged: resistance to change, openness to experience, and opinion leading. The regression model showed that opinion leading and openness to experience were significant predictors of performance.

Conclusion: The IS is three dimensional in the pharmaceutical manager sample. Performance of pharmaceutical managers are affected from opinion leading and openness to experience. This paper has both theoretical and practical contributions.

Keywords: Individual innovativeness, openness to experience, opinion leading, resistance to change, performance
\end{abstract}

*This article is extracted from the Ph.D. thesis of the corresponding author.

\section{INTRODUCTION}

Innovativeness is becoming increasingly important especially in the Industry 4.0 era. Kagermann et al. (2013) reported that Industry 4.0 is generally referred to as the fourth industrial revolution (Grzybowska \& Łupicka, 2017). It leads to new technologies, processes, and important changes in business life (Horváth \& Szabó, 2019). Kovács (2017) stated that technical feasibility and social acceptability have an impact on the success of Industry 4.0 (Horváth \& Szabó, 2019). The pharmaceutical sector has rapid growth, more qualified managers are needed in the fourth industrial revolution (Grzybowska \&
Łupicka, 2017), and innovation is an important growth factor for the pharmaceutical industry (Schuhmacher, Germann, Trill, \& Gassmann, 2013).

Innovation means generating new knowledge and ideas, as well as adopting external practices and processes and applying them (Scott \& Bruce, 1994; Gu, Duverger, \& Yu, 2017). According to Rogers (2002), innovation is "an idea, practice, or object that is perceived as new by an individual or other unit of adoption" and innovativeness is "the degree to which an individual or other unit of adoption is relatively earlier in adopting new ideas than other members of a social system". 
Human resources is a vital parameter in ensuring the dynamism of businesses, mainly in the pharmaceutical industry (Babapour, Gholipourb, \& Mehralian, 2018). The success or failure of a business is directly associated with the success of employees, and employee performance is effective in achieving business goals (Gümüştekin \& Öztemiz, 2005). However, employee performance is a challenging issue and every business cares about improving performance and increasing competitiveness (Inuwa, 2017; Wu \& Lee, 2011). It has been stated that healthy perfectionists show innovative behaviors while achieving goals (Chang, Chou, Liou \& Tu, 2016). The management process is also important and companies need open-minded, creative leaders to implement and standardize new technologies (Horváth \& Szabó, 2019). Additionally, managers contribute to companies' innovation capabilities (Wang \& Dass, 2017). It can be said that adopting innovation is essential to stay ahead of the competition. Industry 4.0 forms the basis of Pharma 4.0 (Kumar, Talasila, Gowrav, \& Gangadharappa, 2020) and Pharma Industry 4.0 technologies enables pharmaceutical firms to provide a competitive advantage in the long term (Ding, 2018). In this context, pharmaceutical manager innovativeness and performance are crucial factors for this changeover.

In existing literature, the IS has been generally used for students (Ertuğ \& Kaya, 2017; Özden, Cevik, \& Sarıtaş, 2019), student teachers (Celik, 2013), teachers (Yilmaz \& Bayraktar, 2014) or consumers (Pallister \& Foxall 1998; Chao, Reid, \& Mavondo, 2012). In addition, this scale has been developed in teacher and student samples (Hurt, Joseph, \& Cook, 1977) and adapted into Turkish in student sample (Kılıçer \& Odabaşı, 2010). Considering the developments, the measurement of employee innovativeness is important. The present study aims to fill this gap by investigating applicability of IS in business life, and exploring how individual innovativeness dimensions influence working performance. For these purposes, firstly the factor structure of the IS is investigated in a manager sample, after that the dimensions' impact on performance are determined.

\section{MATERIALS AND METHODS}

Innovativeness was measured with the IS developed by Hurt et al. (1977). The IS was adapted into Turkish by Kılıçer and Odabaşı (2010) in a student sample. It contains 20 items (twelve positive and eight negative) and four dimensions, which are resistance to change, risk taking, openness to experience and opinion leading. The performance scale (consisting of four items) was used to measure performance. This scale was adapted from Kirkman \& Rosen (1999) by Sigler \& Pearson (2000), and adapted into Turkish by çöl (2008). Both of them were five point Likert-type scales, and items were ordered from (1) strongly disagree to (5) strongly agree.

Population size of the present study consisted of department managers in the pharmaceutical industry that are members of Association of Research-Based Pharmaceutical Companies, Pharmaceutical Manufacturers Association of Turkey and Pharmaceutical Industry Association of Turkey. The associations were informed about the study and their support was requested. Determining the total number of department managers was not possible so sample size was calculated considering the population size as being unknown. Participants were informed about the study by phone call. After their approval, the questionnaire was sent via e-mail. The questionnaires were administered between April and December 2017. The Ankara University Ethical Committee approved this study with permit number 89 (13.03.2017). The minimum sample size was evaluated as 96; on a 0.05 relevance level, d: 0.1 and p: 0.5. 126 managers replied to the questionnaire. Four of them were excluded from the research due to errors and inconsistencies. In total, 122 surveys were included in the analysis.

LISREL 9.2 (Jöreskog \& Sörbom, 2015) and SPSS version 24.0 (IBM Corp. 2016) were used for confirmatory factor analyses and other analyses, respectively.

\section{RESULTS}

$46.7 \%$ of the participants were female, and $53.3 \%$ were male. More than half of the managers (54.1\%) were aged between 30$40,16.4 \%$ of them were under 30 and $29.5 \%$ were over 40 years old. Nearly half of the managers had been working for five or fewer years in their current department. 32\% of the participants were from the sales and/or marketing department (Table 1).

\section{Table 1: Characteristics of the participants.}

\begin{tabular}{|c|c|}
\hline & Frequency $(\%)$ \\
\hline \multicolumn{2}{|l|}{ Gender } \\
\hline Female & 46.7 \\
\hline Male & 53.3 \\
\hline \multicolumn{2}{|l|}{ Age } \\
\hline$<30$ & 16.4 \\
\hline $30-40$ & 54.1 \\
\hline$>40$ & 29.5 \\
\hline \multicolumn{2}{|l|}{ Working Years } \\
\hline$\leq 5$ years & 49.2 \\
\hline $6-10$ years & 23.8 \\
\hline$>10$ years & 27 \\
\hline \multicolumn{2}{|l|}{ Departments } \\
\hline Sales/Marketing & 32 \\
\hline Research\&Development & 10.7 \\
\hline Regulatory Affairs & 8.2 \\
\hline Supply Chain/Logistics & 7.4 \\
\hline Human Resources & 6.6 \\
\hline Quality & 6.6 \\
\hline Medical & 5.7 \\
\hline Others & 23 \\
\hline
\end{tabular}

Kaiser-Meyer-Olkin (KMO) values were determined as 0.809 and 0.795 for IS and Performance Scale (PS), respectively. Also, Bartlett's test of sphericity was significant for both $(p<0.001)$. These values exhibit that the sample size was sufficient, and the data were suitable for exploratory factor analysis (EFA). 
Principal component analysis with varimax rotation was used to conduct EFA. According to the EFA results after removing nine items, the IS consisted of three dimensions: resistance to change (RC), openness to experience (OE), and opinion leading $(\mathrm{OL})$, and the performance scale emerged as unidimensional. The means of each item and factor loadings are shown in Tables 2 and 3. The Cronbach's alpha of the PS was 0.828 and the explained variance $66.312 \%$. Table 4 shows Cronbach's alpha values and variance ratios of IS. Confirmatory factor analyses (CFA) were performed to determine construct validity of the scales. Path diagrams of CFA models are shown in Figures 1 and 2. Rotated factor loadings were over 0.5 for all of the

\section{Table 2: Exploratory factor analysis, factor loadings} and means $(\bar{x})$ of IS.

\begin{tabular}{|c|c|c|c|c|}
\hline \multirow[b]{2}{*}{ Factors and items } & \multirow[b]{2}{*}{$\overline{\mathbf{x}}$} & \multicolumn{3}{|c|}{ Factor loadings } \\
\hline & & $\mathrm{RC}$ & $\mathrm{OE}$ & $\mathrm{OL}$ \\
\hline \multicolumn{5}{|l|}{ RC } \\
\hline ii6 & 2.28 & 0.656 & & \\
\hline ii10 & 2.10 & 0.846 & & \\
\hline ii17 & 2.39 & 0.834 & & \\
\hline ii20 & 2.12 & 0.724 & & \\
\hline \multicolumn{5}{|l|}{$\mathrm{OE}$} \\
\hline ii2 & 4.36 & & 0.794 & \\
\hline ii3 & 4.24 & & 0.857 & \\
\hline ii5 & 4.14 & & 0.588 & \\
\hline ii14 & 4.17 & & 0.600 & \\
\hline \multicolumn{5}{|l|}{ OL } \\
\hline ii8 & 4.20 & & & 0.761 \\
\hline ii9 & 4.16 & & & 0.825 \\
\hline ii12 & 4.33 & & & 0.703 \\
\hline
\end{tabular}

Table 3: Exploratory factor analysis, factor loadings and means $(\bar{x})$ of PS.

\begin{tabular}{|lcc|}
\hline Factor items & $\overline{\mathbf{x}}$ & Factor loadings \\
\hline p1 & 4.39 & 0.813 \\
p2 & 4.41 & 0.823 \\
p3 & 4.27 & 0.812 \\
p4 & 4.30 & 0.810 \\
\hline
\end{tabular}

Table 4: Cronbach's $\alpha$, explained variance and cumulative explained variance values of IS.

\begin{tabular}{|lccc|}
\hline Factors & $\begin{array}{c}\text { Cronbach's } \\
\alpha\end{array}$ & $\begin{array}{c}\text { Variance } \\
(\%)\end{array}$ & $\begin{array}{c}\text { Cumulative } \\
\text { variance (\%) }\end{array}$ \\
\hline RC & 0.775 & 22.022 & 22.022 \\
OE & 0.783 & 21.983 & 44.005 \\
OL & 0.764 & 20.296 & 64.302 \\
\hline
\end{tabular}

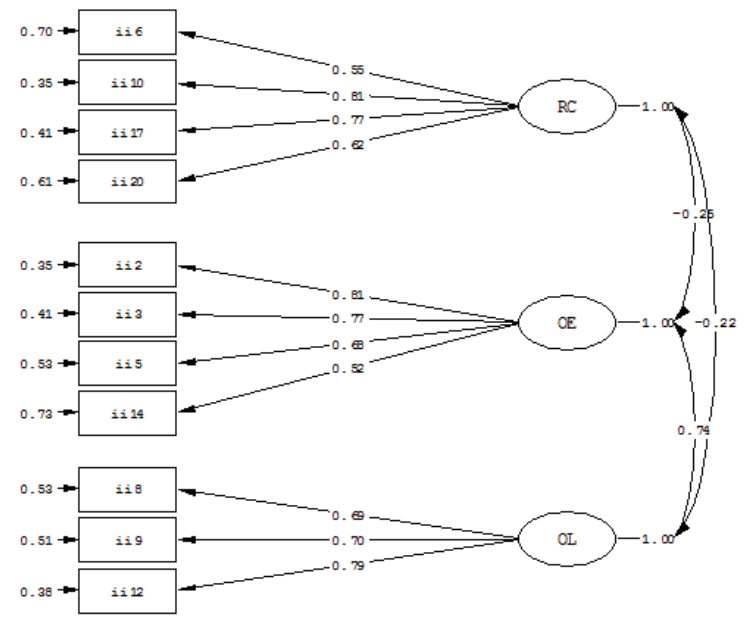

Figure 1. CFA model of the IS.

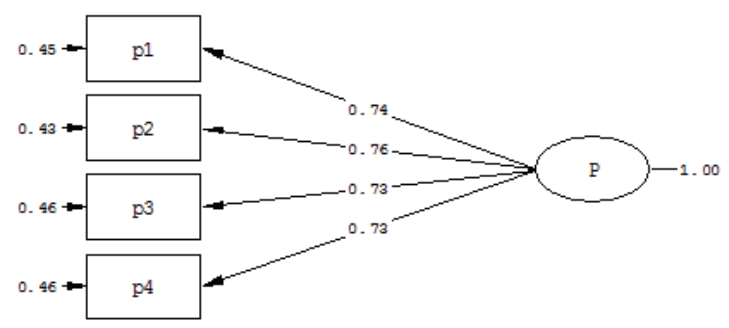

Figure 2. CFA model of the performance scale.

items. Various goodness of fit indices such as chi-square/degree of freedom ( $\left.x^{2} / d f\right)$, p-value, root mean square error of approximation (RMSEA), comparative fit index (CFI), non-normed fit index (NNFI) and standardized root mean square residual (SRMR) were used to examine the fit of model and dataset (Arslan \& Şar, 2018; Tarhan, Arslan \& Şar, 2017; Arslan, Tarhan, \& Şar, 2017). CFA results of IS and PS are shown in Table 5. Goodness of fit indices of three dimensional innovativeness and unidimensional performance scales are: $x^{2} / d f=1.19 ; p$ value $=0.184$; RMSEA $=0.04 ; \mathrm{NNFI}=0.98 ; \mathrm{CFI}=0.98$ good fit; $\mathrm{SRMR}=0.055 \mathrm{ac}-$ ceptable fit, and $X^{2} / d f$ 1.82; $p$ value $=0.162 ; \mathrm{NNFI}=0.97 ; \mathrm{CFI}=0.99$; $\mathrm{SRMR}=0.02$ good fit; RMSEA $=0.08$ acceptable fit, respectively, according to the intervals of the goodness-of-fit indices (Çelik \&Yılmaz, 2016; Hair, Anderson, Tatham, \& Black, 1998; Jöreskog \& Sörbom, 1996; Raykov \& Marcoulides, 2006; Schermelleh-Engel, Moosbrugger, \& Müller, 2003; Yılmaz, Çelik, \& Arslan, 2010). These results exhibit that the CFA models are acceptable.

The CFA results supported that the IS had a three factor structure in manager sample. Pearson's correlation analysis was conducted to exhibit the relations between the variables. Significant positive correlations were found between performance and openness to experience $(r=0.433 ; p=0.00)$, performance and opinion leading ( $r=0.195 ; p=0.016)$. However, no significant relation was identified between performance and resistance to change $(r=-0.039 ; p=0.335)$. Following correlation analysis, regression analysis was performed to find out the influences of IS dimensions on performance. The regression model was significant ( $F=11.576, p=0.000)$. 22.7\% of per- 


\section{Table 5: CFA results of IS and PS.}

\begin{tabular}{|c|c|c|c|}
\hline $\begin{array}{l}\text { Factors and } \\
\text { items }\end{array}$ & $\begin{array}{l}\text { Standardized } \\
\text { loadings }\end{array}$ & $\begin{array}{c}\mathrm{t}^{-} \\
\text {values }\end{array}$ & $\mathbf{R}^{2}$ \\
\hline \multicolumn{4}{|l|}{$\mathrm{RC}$} \\
\hline ii6 & 0.55 & 5.97 & 0.30 \\
\hline ii10 & 0.81 & 9.41 & 0.65 \\
\hline ii17 & 0.77 & 8.84 & 0.59 \\
\hline ii20 & 0.62 & 6.91 & 0.39 \\
\hline \multicolumn{4}{|l|}{$\mathrm{OE}$} \\
\hline ii2 & 0.81 & 9.85 & 0.65 \\
\hline ii3 & 0.77 & 9.26 & 0.59 \\
\hline ii5 & 0.68 & 7.95 & 0.47 \\
\hline ii14 & 0.52 & 5.68 & 0.27 \\
\hline \multicolumn{4}{|l|}{ OL } \\
\hline ii8 & 0.69 & 7.76 & 0.47 \\
\hline ii9 & 0.70 & 7.90 & 0.49 \\
\hline ii12 & 0.79 & 9.16 & 0.62 \\
\hline \multicolumn{4}{|l|}{ PS } \\
\hline p1 & 0.74 & 8.75 & 0.55 \\
\hline p2 & 0.76 & 9.00 & 0.58 \\
\hline p3 & 0.73 & 8.64 & 0.54 \\
\hline p4 & 0.73 & 8.63 & 0.54 \\
\hline
\end{tabular}

formance was determined by the variables $\left(R^{2}=0.227\right)$ and the dimensions openness to experience $(t=5.356, p=0.000)$ and opinion leading $(t=2.411, p=0.017)$ were significant according to the regression results.

The independent samples t-test and one-way analyses of variance (ANOVA) were applied to assess the effects of demographics on the factors. Tukey test was conducted to determine the differences between the groups due to homogeneity of variance. According to the independent samples t-test results, no statistically significant difference was found in gender. ANOVA results showed that age of the participants had statistically significant differences in OL factor ( $F=3.130 ; p=0.047$; $p<0.05$ ). Managers over forty were more opinion leaders than the participants under the age of thirty.

Concerning the working years of the managers in the departments, statistically significant differences were found in RC factor ( $F=2.572 ; p=0.081 ; p<0.1)$. Participants with $6-10$ years of working experience were high in $\mathrm{RC}$ than those working for more than ten years.

\section{DISCUSSION}

This study determined the factor structure of the IS in a pharmaceutical managers sample, thereafter it expressed the impacts of the innovativeness dimensions on performance, and revealed that performance is affected by openness to experience and opinion leading. In addition, the effects of gender, age and working experience on the dimensions were examined.

The present study shows that the IS consists of three dimensions: resistance to change, openness to experience and opinion leading in manager sample. Similar to this study, Gürkan \& Demiralay (2017), applied IS to surgeons and found threedimensions: resistance to change, openness to experience and opinion leadership. Besides, in studies with different samples different dimensions were emerged (Pallister \& Foxall, 1998; Sarığlu, 2014). In the present study, the managers who had been working in the department for more than ten years had less resistance to change than the ones with between 6-10 years of working experience. Supporting this, older managers are found high in opinion leading. Similarly, Kunze, Boehm, \& Bruch (2013) stated that, in contrast to widespread stereotypes, older employees exhibit less resistance to change than their younger counterparts.

Related to the gender of participants, different results occur in the literature. In a study applied to entrepreneurs, females were found to be more open to experience (Hachana, Berraies, \& Ftiti 2018). On the other hand, in a study with managers and employees in the service and industrial sectors, gender was found to not affect innovation and work performance (YIIdı, Baştürk, \& Boz Taştan, 2014). Similarly, in this study, gender did not have a statistically significant effect on the dimensions.

People often try to verify their opinions before reaching a decision. Opinion leaders are described as "those individuals from whom others seek advice and information" and influence other people's ideas (Rogers \& Cartano, 1962). Opinion leaders exhibit high levels of exploratory behavior, engage in intense activities, follow developments in their interests, and have a higher tendency to assess, test, accept and adopt innovations (Chen, Weng, Yang, \& Tseng, 2018; Goldsmith \& Desborde, 1991). In this context, the performance of individuals with such behaviors is expected to be high. The current study shows that opinion leading affects performance positively. In the literature, studies about opinion leadership are generally examined on consumers. In a study conducted by Cho \& Workman (2011), in the field of fashion, only one shopping channel is used by the consumers with low innovativeness and opinion leadership. However, more channel types are used by the participants with high innovativeness and opinion leadership. Another study conducted on consumers determined that opinion leadership increases the likelihood of subscribing to and reading computer-related journals, and going to computer stores (Shoham \& Ruvio, 2008). As mentioned above, it can be thought that intense activities can improve performance.

Innovation is a critical parameter for individuals and the growth of businesses and economies. In the globalizing world, early implementation of innovations helps to gain competitive advantage (Vila, Perez, \& Coll-Serrano, 2014). Interactions in the working environment affects innovative behaviors (Anderson, de Dreu \& Nijstad, 2004; Zhou \& Shalley, 2003; De Jong \& Den Hartog, 2007) and managers have important roles in influencing innovativeness in institutions (Kılıçer \& Odabaşı, 2013). Personality affects the opinions, emotions and behaviors of 
employees, and also it is effective in behaviors in daily life and particularly in the working environment (Darmawan, 2017). Openness to experience has been stated to be a personality trait (McCrae \& Costa, 1987; Harris, 2004). Individuals defined as 'open' are more prone to new and diverse experiences (Williams, 2004). In the present study, this dimension positively affected performance. Among the dimensions of innovativeness, openness to experience is found to be the most critical factor affecting performance. Individuals high in openness are more open to feedback and more adapted to the activities and relationships in organizations (Bartone, Eid, Johnsen, Laberg, \& Snook, 2009). Darmawan (2017) conducted a study with employees from different companies, and pointed out that openness to experience has a positive effect on performance. Moreover, a study conducted with chief managers working in small and medium-sized production enterprises stated that managers' openness to experience have significant effects on the understanding of budgeting practices (Zor, Linder, \& Endenich, 2019). In the literature, there are various results relating to the impact of openness to experience on performance. In a study applied to employees who make telephone sales in two large telecom firms, no relationship was found between openness to experience and performance (Klang, 2012). In another study, it was stated that openness had no effect on leader performance (Bartone et al., 2009). Openness may be an important factor affecting performance in situations where employees have to adapt to changes, but in stable situations its effect is less (Thoresen, Bradley, Blıese, \& Thoresen, 2004).

In this study, the resistance to change did not have a statistically significant impact on performance. Additionally, responses to resistance to change was low. In this context, it can be said that managers working in the pharmaceutical industry do not exhibit resistance to change. Success or failure of a company depends on competent employees (Adolph, Tisch, \& Metternich, 2014). Resistance to change can be considered as an undesirable condition in fields where many changes and innovations take place, such as the pharmaceutical industry. Therefore, according to the findings, it can be considered that manager traits are taken into account in recruitment and promotion situations. In addition, the managers' performance was found to be high. Low resistance to change and high-performance are expected findings, especially in the pharmaceutical industry.

\section{CONCLUSION}

Innovations and innovativeness are becoming more and more important during the period of Industry 4.0 and are expected to continue to be important as time goes on. The present study has theoretical and practical contributions in business management. IS has a three factor structure in a manager sample. The three dimensional IS can be used in recruitment and promotion stages by organizations. This study provides contributions about exploring how personality traits impact performance. Openness to experience and opinion leading are found to be performance predictors. In recruitment and promotion stages, human resource departments can give priority to the candidates who rank high in openness to experience and opinion leading. The present study sampled managers in the pharmaceutical industry. Future studies can be performed in employee samples and/or different sectors.

Acknowledgement: The authors want to thank Association of Research-Based Pharmaceutical Companies, Pharmaceutical Manufacturers Association of Turkey, Pharmaceutical Industry Association of Turkey and the managers participated in this study.

Peer-review: Externally peer-reviewed.

Informed Consent: Written consent was obtained from the participants.

Ethics Committee Approval: This study was approved by the Ethical Committee of the Ankara University (No:89).

Author Contributions: Conception/Design of Study- N.T., S.Ş.; Data Acquisition-N.T.; Data Analysis/Interpretation-N.T.; Drafting Manuscript-N.T.; Critical Revision of Manuscript- N.T., S.Ş.; Final Approval and Accountability- N.T., S.Ş.

Conflict of Interest: The authors have no conflict of interest to declare.

Financial Disclosure: Authors declared no financial support.

\section{REFERENCES}

- $\quad$ Adolph, S., Tisch, M., \& Metternich, J. (2014). Challenges and approaches to competency development for future production. Journal of International Scientific Publications-Educational Alternatives, 12(1), 1001-1010.

- $\quad$ Anderson, N. R., de Dreu, C. K. W., \& Nijstad, B. A. (2004). The routinization of innovation research: a constructively critical review of the state-of-the-science. Journal of Organizational Behavior, 25, 147-173.

- $\quad$ Arslan, M., Tarhan, N., \& Sar, S. (2017). Examination of the community pharmacists' intention to pharmacist partnership using the theory of planned behavior: a structural equation model. Indian Journal of Pharmaceutical Education and Research, 51(2), 216-225.

- $\quad$ Arslan, M., \& Şar, S. (2018). Examination of environmentally friendly "green" logistics behavior of managers in the pharmaceutical sector using the theory of planned behavior. Research in Social and Administrative Pharmacy, 14(11), 1007-1014.

- Babapour, J., Gholipourb, A., \& Mehralian, G. (2018). Human resource management challenges to develop pharmaceutical industry: evidence from developing countries. Iranian Journal of Pharmaceutical Research, 17(Suppl2), 224-238.

- $\quad$ Bartone, P. T., Eid, J., Johnsen, B. H., Laberg, J. C., \& Snook, S. A. (2009). Big five personality factors, hardiness, and social judgment as predictors of leader performance. Leadership \& Organization Development Journal, 30(6), 498-521.

- Celik, K. (2013). The relationship between individual innovativeness and self-efficacy levels of student teachers. International Journal of Scientific Research in Education, 6(1), 56-67.

- Chao, C. W., Reid, M., \& Mavondo, F. T. (2012). Consumer innovativeness influence on really new product adoption. Australasian Marketing Journal (AMJ), 20(3), 211-217.

- $\quad$ Chang, H. T., Chou, Y. J., Liou, J. W., \& Tu, Y. T. (2016). The effects of perfectionism on innovative behavior and job burnout: Team workplace friendship as a moderator. Personality and Individual Differences, 96, 260-265.

- $\quad$ Chen, C. P., Weng, J. Y., Yang, C. S., \& Tseng, F. M. (2018). Employing a data mining approach for identification of mobile opinion leaders and their content usage patterns in large telecommunications datasets. Technological Forecasting and Social Change, 130, 88-98. 
• Cho, S., \& Workman, J. (2011). Gender, fashion innovativeness and opinion leadership, and need for touch: Effects on multi-channel choice and touch/non-touch preference in clothing shopping. Journal of Fashion Marketing and Management, 15(3), 363-382.

- Çelik, H. E., \& Yılmaz, V. (2016). LISREL 9.1 ile yapısal eşitlik modellemesi temel kavramlar, uygulamalar, programlama ( $3^{\text {th }}$ ed.) [Structural equation modeling with LISREL 9.1 basic concepts, applications, programming]. Ankara: Anı Yayıncılık.

- Çق̈l, G. (2008). Algılanan güçlendirmenin işgören performansı üzerine etkileri [The effects of perceived empowerment on employee performance]. Doğuş Üniversitesi Dergisi, 9(1), 35-46.

- Darmawan, D. (2017). The effect of the big five personality on job performance. Management \& Accounting Research Journal, 2(1), 36-42.

- De Jong, J. P. J, \& Den Hartog, D. N. (2007). How leaders influence employees' innovative behaviour. European Journal of Innovation Management, 10(1), 41-64.

- Ding, B. (2018). Pharma industry 4.0: Literature review and research opportunities in sustainable pharmaceutical supply chains. Process Safety and Environmental Protection, 119, 115-130.

- $\quad$ Ertuğ, N., \& Kaya, H. (2017). Hemşirelik Öğrencilerinin Bireysel Yenilikçilik Profilleri ve Yenilikçiliğin Önündeki Engellerin İncelenmesi [Investigating the individual innovativeness profiles and barriers to innovativeness in undergraduate nursing students]. Hemşirelikte Eğitim ve Araştırma Dergisi (HEAD), 14(3), 192-197.

- Goldsmith, R. E., \& Desborde, R. (1991). A validity study of a measure of opinion leadership. Journal of Business Research, 22(1), 11-19.

- Grzybowska, K., \& Łupicka, A. (2017). Key competencies for Industry 4.0. Economics \& Management Innovations, 1(1), 250-253.

- $\quad$ Gu, H., Duverger, P., \& Yu, L. (2017). Can innovative behavior be led by management? A study from the lodging business. Tourism Management, 63, 144-157.

- Gümüştekin, G. E., \& Öztemiz, A. B. (2005). Örgütlerde stresin verimlilik ve performansla etkileşimi [Productivity and performance interaction with stres of organizations]. Çukurova Üniversitesi Sosyal Bilimler Enstitüsü Dergisi, 14(1), 271-288.

- Gürkan, G. C., \& Demiralay, T. (2017). Bireysel yenilikçiliğin çalışanın yenilikçi davranışı üzerindeki etkisinde içsel motivasyonun araclık rolü: Türkiye'de cerrahlar örneği. [The mediator effect of intrinsic motivation on the relationship between individual innovativeness and employee's innovative behavior: the case of surgeons in Turkey]. Journal of Entrepreneurship and Innovation Management. 6(1), 65-90.

- Hachana, R., Berraies, S., \& Ftiti, Z. (2018). Identifying personality traits associated with entrepreneurial success: does gender matter? Journal of Innovation Economics \& Management, art321$\operatorname{art32XXV.}$

- Hair, F. J., Anderson, E. R., Tatham, L. R., \& Black, C. W. (1998). Multivariate data analysis. New Jersey: Prentice Hall.

- Harris, J. A. (2004). Measured intelligence, achievement, openness to experience, and creativity. Personality and Individual Differences, 36(4), 913-929.

- Horváth, D., \& Szabó, R. Z. (2019). Driving forces and barriers of Industry 4.0: Do multinational and small and medium-sized companies have equal opportunities? Technological Forecasting and Social Change, 146, 119-132.

- Hurt, H. T., Joseph, K., \& Cook, C. D. (1977). Scales for the measurement of innovativeness. Human Communication Research, 4(1), 58-65.

- IBM Corp. (2016). IBM SPSS Statistics Base for Windows, Version 24.0. Armonk, NY: IBM Corp.

- Inuwa, M. (2017). Relationship between job equity and performance of employee : A literature review. International Journal of Business and Management Future, 1(1), 8-15.
Jöreskog, K. G., \& Sörbom, D. (2015). LISREL 9.2 for Windows [Computer software]. Skokie, IL: Scientific Software International, Inc.

- Jöreskog, K. G., \& Sörbom D. (1996). LISREL 8: User's reference guide, Scientific Software International, Chicago.

Kagermann, H., Wahlster, W., Helbig, J., Hellinger, A., Stumpf, V., \& Kobsda, C. (2013). Umsetzungsempfehlungen für das Zukunftsprojekt Industrie 4.0 - Abschlussbericht des Arbeitskreises Industrie 4.0. Berlin.

Kılıçer, K., \& Odabaşı, H. F. (2010). Bireysel yenilikçilik ölçeği (BYÖ): Türkçeye uyarlama, geçerlik ve güvenirlik çalışması [Individual innovativeness scale (IS): the study of adaptation to Turkish, validity and reliability]. Hacettepe University Journal of Education, 38, 150164.

- Kirkman, B. L., \& Rosen, B. (1999). Beyond self-management: Antecedents and consequences of team empowerment. Academy of Management Journal, 42, 58-74.

- K Kılıçer, K., \& Odabaşı, H. F. (2013). Exploring the perceived barriers to innovativeness: views of Turkish pre-service teachers as technology leaders. Hacettepe University Journal of Education, 28, 246-265.

- Klang, A. (2012). The relationship between personality and job performance in sales: a replication of past research and an extension to a Swedish context (Master Thesis). Retrieved from https:// www.diva-portal.org/smash/get/diva2:542263/FULLTEXT01.pdf

- Kovács, O. (2017). Az Ipar 4.0 komplexitása - I Közgazdasági Szle, 64, 823-851.

- Kumar, S. H., Talasila, D., Gowrav, M. P., \& Gangadharappa, H.V. (2020). Adaptations of pharma 4.0 from industry 4.0. Drug Invention Today, 14(3), 405-415.

- Kunze, F., Boehm, S., \& Bruch, H. (2013). Age, resistance to change, and job performance. Journal of Managerial Psychology, 28(7/8), 741-760.

- McCrae, R. R., \& Costa, P. T. (1987). Validation of the five-factor model of personality across instruments and observers. Journal of Personality and Social Psychology, 52(1), 81-90.

- $\quad$ Özden, G., Cevik, S., \& Sarıtaş, S. Ç. (2019). Do the online information searching strategies affect individual innovativeness in nursing students? Annals of Medical Research, 26(4), 629-635.

- Pallister, J. G., \& Foxall, G. R. (1998). Psychometric properties of the Hurt-Joseph-Cook scales for the measurement of innovativeness. Technovation, 18(11), 663-675.

- $\quad$ Raykov, T., \& Marcoulides, G. A. (2006). A first course in structural equation modeling. Mahwah, New Jersey, London: Lawrence Erlbaum Associates.

Rogers, E. M. (2002). Diffusion of preventive innovations. Addictive Behaviors, 27, 989-993.

- $\quad$ Rogers, E. M., \& Cartano, D. G. (1962). Methods of measuring opinion leadership. Public Opinion Quarterly, 26, 435-441.

- Sarıŏlu, A. (2014). Bireysel yenilikçilik ölçeğinin hemşirelikte geçerlik ve güvenirliği (Master Thesis). Retrieved from tez.yok.gov. tr/UlusalTezMerkezi/tezSorguSonucYeni.jsp

- $\quad$ Schermelleh-Engel, K., Moosbrugger, H., \& Müller, H. (2003). Evaluating the fit of structural equation models: Tests of significance and descriptive goodness-of-fit measures. Methods of Psychological Research, 8(2), 23-74.

- $\quad$ Schuhmacher, A., Germann, P. G., Trill, H., \& Gassmann, O. (2013). Models for open innovation in the pharmaceutical industry. Drug Discovery Today, 18(23-24), 1133-1137.

- Scott, S. G., \& Bruce, R. A. (1994). Determinants of innovative behavior: A path model of individual innovation in the workplace. The Academy of Management Journal, 37(3), 580-607.

Shoham, A., \& Ruvio, A. (2008). Opinion leaders and followers: A replication and extension. Psychology \& Marketing, 25(3), 280297. 
- $\quad$ Sigler, T. H., \& Pearson, C. M. (2000). Creating an empowering culture: examining the relationship between organizational culture and perceptions of empowerment. Journal of Quality Management, 5, 27-52.

- Tarhan, N., Arslan, M., \& Şar, S. (2017). A structural equation model for pharmacy students' acquiring knowledge-based behavior towards complementary and alternative medicine. European Journal of Integrative Medicine, 16, 54-60.

- Thoresen, C. J., Bradley, J. C., Blıese, P. D., \& Thoresen, J. D. (2004). The big five personality traits and individual job performance growth trajectories in maintenance and transitional job stages. Journal of Applied Psychology, 89(5), 835-853.

- Vila, L. E., Perez, P. J., \& Coll-Serrano, V. (2014). Innovation at the workplace: Do professional competencies matter? Journal of Business Research, 67, 752-757.

- Wang, X., \& Dass, M. (2017). Building innovation capability: The role of top management innovativeness and relative-exploration orientation. Journal of Business Research, 76, 127-135.

- Williams, S. D. (2004). Personality, attitude, and leader influences on divergent thinking and creativity in organizations. European Journal of Innovation Management, 7(3),187-204.
- Wu, M. Y., \& Lee, Y. R. (2011). The effects of internal marketing, job satisfaction and service attitude on job performance among high-tech firm. African Journal of Business Management, 5(32), 12551-12562.

- $\quad$ Yıldız, S., Baştürk, F., \& Boz Taştan I. (2014). The effect of leadership and innovativeness on business performance. Procedia-Social and Behavioral Sciences, 150, 785-793.

- $\quad$ Yılmaz, V., Çelik, H. E., \& Arslan, M. S.T. (2010). Enerji çeşitleri ve geri dönüşüme karşı tutumların çevresel davranışa etkisi [Effects of attitude towards energy variety and recycling on environmental behaviors]. Firat University Journal of Social Science, 20(2), 323-342.

- Yilmaz, O., \& Bayraktar, D.M. (2014). Teachers' attitudes towards the use of educational technologies and their individual innovativeness categories. Procedia-Social and Behavioral Sciences, 116, 3458-3461.

Zhou, J., \& Shalley, C. E. (2003). Research on employee creativity: a critical review and proposal for future research directions. In Martocchio, J. J. \& Ferris, G. R. (Eds), Research in Personnel and Human Resource Management, Elsevier, Oxford.

Zor, U., Linder, S., \& Endenich, C. (2019). CEO characteristics and budgeting practices in emerging market SMEs. Journal of Small Business Management, 57(2), 658-678. 